\title{
Erratum: An Exploration of Food Insecurity, Poverty, Livelihood and Local Food Potentials in Kulon Progo Regency, Indonesia
}

\author{
Dodi Widiyanto \\ Graduate School of Environmental Studies, Nagoya University, Furo-cho, Chikusa-ku, Nagoya, \\ 464-8601, Japan. \\ The Faculty of Geography, Universitas Gadjah Mada, Jl. Kaliurang Km. 5 Bulaksumur, Sleman, \\ Yogyakarta 55281, Indonesia. \\ Corresponding author (e-mail: dodi.widiyanto@ugm.ac.id)
}

Received: 02 December 2018 / Accepted: 17 December 2018 / Published: 16 January 2019

\begin{abstract}
This erratum aims to revise a mistake from the previous article (Widiyanto, 2018). The mistake is mainly about the presentation of a table for the Appendix 3, i.e. Local Food Production Potential. There was a mistake for the Ngestiharjo village Local Food Production Potential figure, particularly for the tuber/uwi (8). The correct value for this is provided here.
\end{abstract}

Abstrak. Erratum ini bertujuan untuk memperbaiki kesalahan dari artikel sebelumnya (Widiyanto, 2018). Kesalahannya terutama tentang penyajian tabel untuk Lampiran 3, yaitu Potensi Produksi Pangan Lokal. Ada kesalahan angka Potensi Produksi Pangan di desa Ngestiharjo, terutama untuk umbi/uwi (column $8^{\text {th }}$ ). Nilai yang benar untuk ini disediakan di sini.

\section{Erratum}

Widiyanto (2018) presents a table for the appendix 3 that contains a mistake, i.e. for the table of Local Food Production Potential. The mistake is for the Ngestiharjo village Local Food Production Potential figure, particularly for the tuber/uwi (8) information. The Table 1 here presents the original value, while the Table 2 provides the correct value.

Table 1. Original value.

\begin{tabular}{ccccccccccccc}
\hline Village & $\begin{array}{c}\text { Geographical } \\
\text { Zone }\end{array}$ & Type & $(1)$ & $(2)$ & $(3)$ & $(4)$ & $(5)$ & $(6)$ & $(7)$ & $(8)$ & $(9)$ & $(10)$ \\
\hline Ngestiharjo & Lowland & M-L & L & L & M & L & L & L & L & L & M & L \\
\hline \multicolumn{10}{c}{ Table 2. Revised value. } \\
\hline Village & $\begin{array}{c}\text { Geographical } \\
\text { Zone }\end{array}$ & Type & $(1)$ & $(2)$ & $(3)$ & $(4)$ & $(5)$ & $(6)$ & $(7)$ & $(8)$ & $(9)$ & $(10)$ \\
\hline Ngestiharjo & Lowland & M-L & L & L & M & L & L & L & L & M & M & L \\
\hline
\end{tabular}

\section{References}

Widiyanto, D. (2018). An Exploration of Food Insecurity, Poverty, Livelihood and Local Food Potentials in Kulon Progo Regency, Indonesia. Forum Geografi, 32(1), 64-87-87. https://doi.org/10.23917/forgeo.v32i1.5818. 